Magyar Honvédség Egészségügyi Központ ${ }^{1}$

NATO Támogató és Beszerzési Ügynökség (NSPA)²

\title{
Konszenzuskeresés a katasztrófák tudományos kutatásának egységesítésében az Utstein irányelvek alapján
}

\author{
Dr. Kopcsó István orvos dandártábornok ${ }^{1} \mathrm{PhD}$, \\ Dr. Balázs Róbert ${ }^{2}$
}

Kulcsszavak: katasztrófa, biztonság, katasztrófa medicina, jó gyakorlat, Utstein irányelvek, Sendai Framework, kvalitatív és kvantitatív analizis, indikátor rendszer

\begin{abstract}
A katasztrófák előfordulásának gyakorisága világszerte folyamatosan növekszik, azok pusztító hatása egyre több embert érint, halált, szenvedést és jelentős gazdasági károkat okozva. Ezzel egyuitt a katasztrófák regisztrálása és összegyüjtött adatainak minősége is javult az utóbbi években.

Az ENSZ „Hivatal a Katasztrófa Kockázat Csökkentésére (UNISDR)" adatai szerint 2005 és 2014 között több mint 1,7 milliárd embert érintett valamilyen katasztrófa, ebböl 700000 ember meghalt a katasztrófa következményeitől és a becsült anyagi kár elérte az 1400 milliárd USD-t. A rendelkezésre álló - nem standardizált - adatok alapján elmondható, hogy a katasztrófák egyre több ember életét keserítik meg és a gazdasági károk drámai mértékben emelkednek.

Bizonyos típusú katasztrófák meghatározott körülmények között jelentős biztonsági kockázatot is jelenthetnek egy-egy ország, régió vagy akár egy egész földrész számára is. Gondolhatunk itt elsősorban az ember által okozott katasztrófákra úgy, mint háborúk, háborús konfliktusok, vagy a nukleáris-vegyibiológiai fegyverhez vagy ahhoz köthető eseményekre. Véleményünk szerint különös figyelmet igényel a tradicionális klasszifikációkban még érthető módon nem szereplő tömeges (nagyrészt illegális) migráció, mint potenciális katasztrófa kategória (1. ábra), amely elégtelen menedzselés esetén akár az érintett ország (térség) alapvető társadalmi funkcióinak jelentős részét is ne-
\end{abstract}


gatívan befolyásolhatja, ami további kedvezőtlen folyamatokat gerjeszthet.

Értekezésünk a katasztrófáknak az egészségügyi rendszerekre és az egészségügyi ellátásra gyakorolt hatásaival foglalkozik, a kérdéskört - egy, a medicina igen csak új tudományága - a katasztrófa-orvostan szemszögéböl vizsgálva. A tapasztalatok szerint az alapvető társadalmi funkciók közül az egészségügyi rendszer az, ami szinte kivétel nélkül érintve van minden katasztrófában. Ez az érintettség lehet direkt, tehát az egészségügyi infrastruktúra közvetlen károsodása, vagy indirekt amikor az érintett populáció megszokott színvonalú egészségügyi ellátása szenved csorbát.

\section{A katasztrófák kutatásának módszertani kerete}

Napjainkban az egyik legfontosabb világméretü program a katasztrófa-megelőzés és kárcsökkentés tekintetében az ENSZ Közgyülése által 2015-ben jóváhagyott Sendai „Keretegyezmény, a Katasztrófa Kockázat Csökkentésére 20152030." Ez az egyezmény számtalan fontos célt tüzött ki a következő 15 évre. Ezen célok a katasztrófák által okozott halálozást, gazdasági károkat, a kritikus infrastruktúra érintettségét szeretnék nagymértékben csökkenteni. További cél, hogy a leginkább veszélyeztetett államok a lehető legjobb jobb katasztrófa megelőzési stratégiákat dolgozzanak ki, növeljék a nemzetközi kooperációt a hasonló kockázatokkal rendelkező országokkal és végül dolgozzanak ki korai veszélyre figyelmeztető rendszereket és biztosítsanak az ehhez való széleskörű hozzáférést.

A Sendai Keretegyezmény a fentieken kívül prioritásokat is megjelöl a résztvevő államok részére. Legfontosabb, hogy minden állam megértse a kockázatoknak való kitettségét, a sérülékenysége fokát, a lakosságot és a javakat fenyegető veszélyeket. Prioritásként kell kezel- ni a katasztrófa kockázat megelőzésével és kezelésével megbízott állami szervek megerősítését, valamint növelni kell a katasztrófa kockázat kitettséggel szembeni ellenállóképességet, a katasztrófára való felkészültséget és az arra adott választ. A katasztrófa lezajlása és felszámolása után fontos, hogy az infrastruktúra, lehetőleg az eredetinél erősebb és ellenállóbb módon kerüljön helyreállításra.

A katasztrófa kutatás módszertani kereteinek konszenzus alapján történő meghatározása szükséges és elengedhetetlenen ahhoz, hogy a tudomány módszereivel vizsgálhassuk. A katasztrófákkal kapcsolatos beszámolok, esetleírások legtöbbször különböző szemszögből, a fogalmakat keverve, felcserelve számolnak be az eseményről. A katasztrófát és annak hatására kialakult állapotot, a kárfelszámolás során történt eseményeket nem tagolva, fázisokra bontva taglalják, ezért a beszámolók összehasonlíthatósága nem egyszerü vagy éppen lehetetlen.

A cikkben leírt módszertani keret tisztázza a fogalmakat (veszély, kockázat, sérülékenység, társadalomi felkészültség az adott veszélyre stb.) és megoldást nyújt a hossz- és keresztmetszeti elemzésre az 


\section{KATASZTRÓFÁK FELOSZTÁSA}

1. Természeti katasztrófák

1.1. Szeizmikus

1.1.1. Földrengés

1.1.2. Vulkán kitörés

1.1.3. Cunami/szökőár

1.1.4. Kőzetlemezek ütközése

1.2. Meteorológiai/Klimatikus

1.2.1. Szélviharok

1.2.1.1. Orkán

1.2.1.2. Vihar

1.2.1.3. Trópusi ciklon, hurrikán, tájfun

1.2.1.4. Tornádó

1.2.2. Csapadék

1.2.2.1. Eső

1.2.2.2. Hó

1.2.2.3. Jégeső

1.2.3. Villámlás - tüz

1.2.4. Extrém hőmérséklet

1.2.4.1. Kánikula

1.2.4.2. Hideg/fagy

1.2.5. Talajerózió

1.2.6. Szárazság

1.2.7. Elsivatagosodás

1.2.8. Árvíz

1.2.9. Lavina

2. Kevert, természeti és ember okozta

katasztrófák

2.1. Szárazság

2.2. Elsivatagosodás

2.3. Árvíz

2.4. Talajerózió
2.5. Földcsuszamlás/sárlavina

2.6. Tüz/Erdőtüz

2.7. Egészségügyi katasztrófák

2.7.1. Járványok

2.7.2. Genetikai szelekció katasztrófák miatt (Toba vulkán)

2.7.3. Egyéb

3. Ember okozta katasztrófák

3.1. Technológiai

3.1.1. Szennyező anyagok

3.1.1.1. Kémiai

3.1.1.2. Biológiai

3.1.1.3. Nukleáris/sugárzó

3.1.2. Közlekedési

3.1.3. Épületek hibái

3.1.4. Robbanás

3.1.5. Tüz

3.1.6. Környezet egyéb károsítása

3.2. Konfliktusok

3.2.1. Fegyveres konfliktusok

3.2.1.1. Konvencionális háború (hadseregek között)

3.2.1.2. Polgárháború

3.2.1.3. Komplex humanitárius katasztrófák

3.2.1.4. Terrorizmus

3.2.1.5. Tömeges migráció

3.2.1.6. Egyéb

3.2.2. Nem fegyveres konfliktusok

3.2.2.1. Gazdasági szankciók

3.2.2.2. Embargó

1. ábra. Katasztrófát okozó veszélyek osztályozása

(Knut Ole Sundnes: Health Disaster Management: Guidelines for Evaluation and Research 2003 - nyomán módosítva)

adott veszély miatt kialakult katasztrófa lefolyása és felszámolási folyamata tekintetében. Ez az egységes szemléletü megközelítés a fogalmakat illetően elengedhetetlen a kutatás standardizálásának kialakításához, amely alapvető eleme a különböző kutatási eredmények összevethetőségének.

\section{A katasztrófák fázisai}

\section{Hosszmetszeti (longitudinális)}

A hosszmetszeti keret kronológiai sorrendben osztja fázisokra a katasztrófa lefolyását. Az egyes fázisok definícióját a tulajdonságuk, és nem időegységek alapján kerülnek meghatározásra, ezért a 


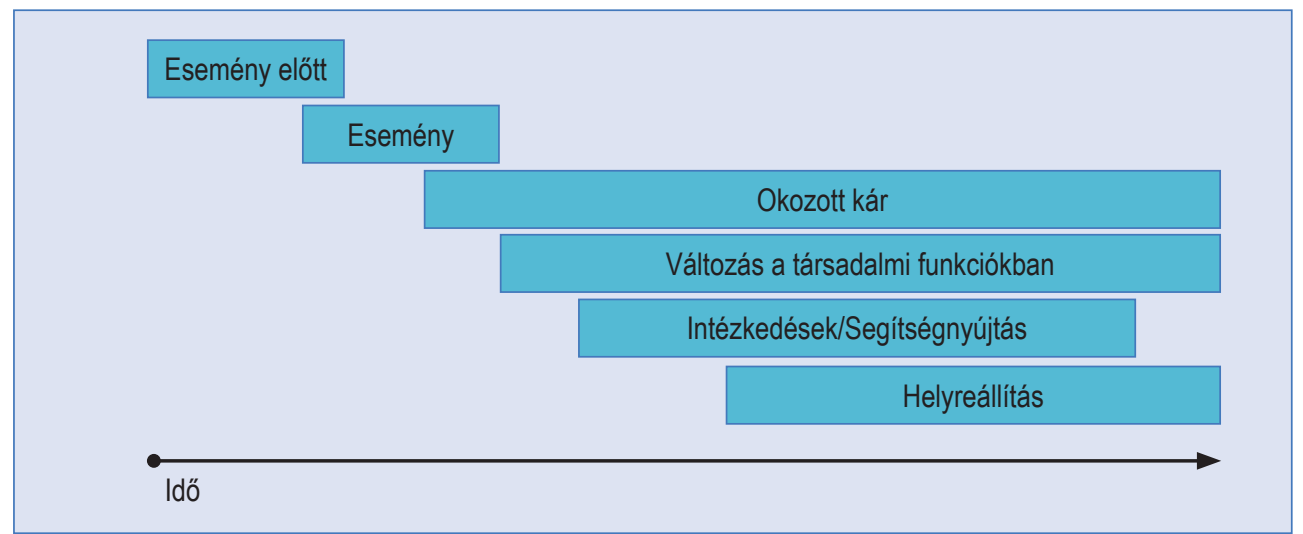

2. ábra. Katasztrófa hosszirányú (longitudinális) metszete. A fázisok idörendje megszabott, hosszuk pedig változó, átfedhetik egymást, illetve egyszerre történhetnek. A kár és a sérült társadalmi funkciók csak a helyreállitás végén lesznek felszámolva.

(Forrás: Scandinavian Journal of Public Health, 2014, 42: 27.)

fázisok rugalmasan tudják követni és értelmezni a különböző katasztrófák eltérő idő intervallumait.

Ezek a fázisok a hosszmetszeti keretben:

A) az eseményt közvetlenül megelőző időszak,

B) az esemény, amelynek hatására a katasztrófa bekövetkezik,

C) az okozott kár,

D) változás egyes alapvető társadalmi funkciókban,

E) intézkedések/segítségnyújtás,

F) helyreállítás.

A hosszmetszeti keret (2. ábra) alkalmazható minden katasztrófa esetében, az egyes fázisok időtartamai az adott katasztrófa lezajlása alapján eltérő hoszszúságúak lesznek. Például egy szárazság esetén az esemény fázis akár több hónapig is tarthat és azt követően jelentkeznek a károk, míg egy folyó szintjének emelkedése viszonylag hamar okoz árvizet, de még mindig napok vannak a felkészülésre. Egy szökőár (cunami) nagyon gyorsan, percek alatt átvált $\mathrm{az}$ esemény fázisból a kár okozás fázisába, amennyiben lakott területet ér el az árhullám.

\section{Keresztmetszeti (transzszekcionális)}

A keresztmetszeti keret ,a katasztrófa kutatásban az egy adott időpillanatban zajló eseményeket, változásokat vizsgálja az alapvető társadalmi funkciókban bekövetkezett állapotváltozás tükrében.

Alapvető társadalmi funkciók (ATF): 1.orvosi ellátás/egészségügyi ellátás,

2. közegészségügy,

3.ivóvíz és szennyvíz szolgáltatás,

4. élelmiszerellátás és közétkeztetés,

5. energiaszolgáltatás,

6. logisztika és szállítás,

7.közbiztonság,

8. közoktatás,

9. társadalmi rendszerek,

10. lakhatás és ruházkodás,

11.hírközlés/kommunikáció,

12.gazdaság,

13. közösségi terek és infrastruktúra.

A hossz- és keresztmetszeti keretek bevezetése lehetőséget ad, a katasztrófák kutatási módszereinek és szemléletének 
egységesítésére, ami a kutatási anyagokat összehasonlíthatóvá teszi (3. ábra). A módszer tehát nemcsak egy adott katasztrófa értékelése esetén működik, hanem olyankor is, amikor azonos jellegü katasztrófák (pl. földrengés), illetve különböző típusú események (földrengés és hurrikán) okozta károk összehasonlítását kell elvégeznünk.

Az ATF-k tekintetében az értékelés elvégzéséhez szükség van ún. indikátorok alkalmazására, amelyek részben rendelkezésre állnak, más részük az Utstein Munkacsoport (UKEM) által került kidolgozásra és a közeljövőben kerül publikálásra. Bizonyos ATF-k további részfunkciókkal is rendelkeznek, amelyek szintén tovább bonthatók különböző elemekre, illetve részelemekre.

Ezen túlmenően megemlítendő, hogy egyes nem-kormányzati szervezetek és nemzetközi segélyszervezetek (Orvosok Határok Nélkül, Vörös Kereszt, stb.) ál- tal menedzselt Sphere Project rendelkezik néhány olyan indikátorral, amelyeket a katasztrófa elhárítás során már mérnek és használnak. Ezen változók alkalmazása már most is nagyban megkönnyíti a humanitárius műveletek során használandó minimum sztenderdek kidolgozását és alkalmazását. Munkacsoportunk vonatkozásában pedig lehetővé teszik az ATF-k mérhetőségét és kiértékelhetőségét a katasztrófák minden fázisában.

\section{Operatív (müveleti) megfontolások}

A tudományos kutatási módszerek egyik fajtája az úgynevezett intervenciós módszer, amikor valamilyen beavatkozás hatásait vizsgálják a megfigyelt rendszeren. A második típust az epidemiológiai kutatások képviselik, amikor non-intervenciós módszer kerül alkalmazásra és a kutatás nem avatkozik be magába a rendszerbe, azt csak megfigyeli és leírja. A katasztrófa-egészségügyben az opera-

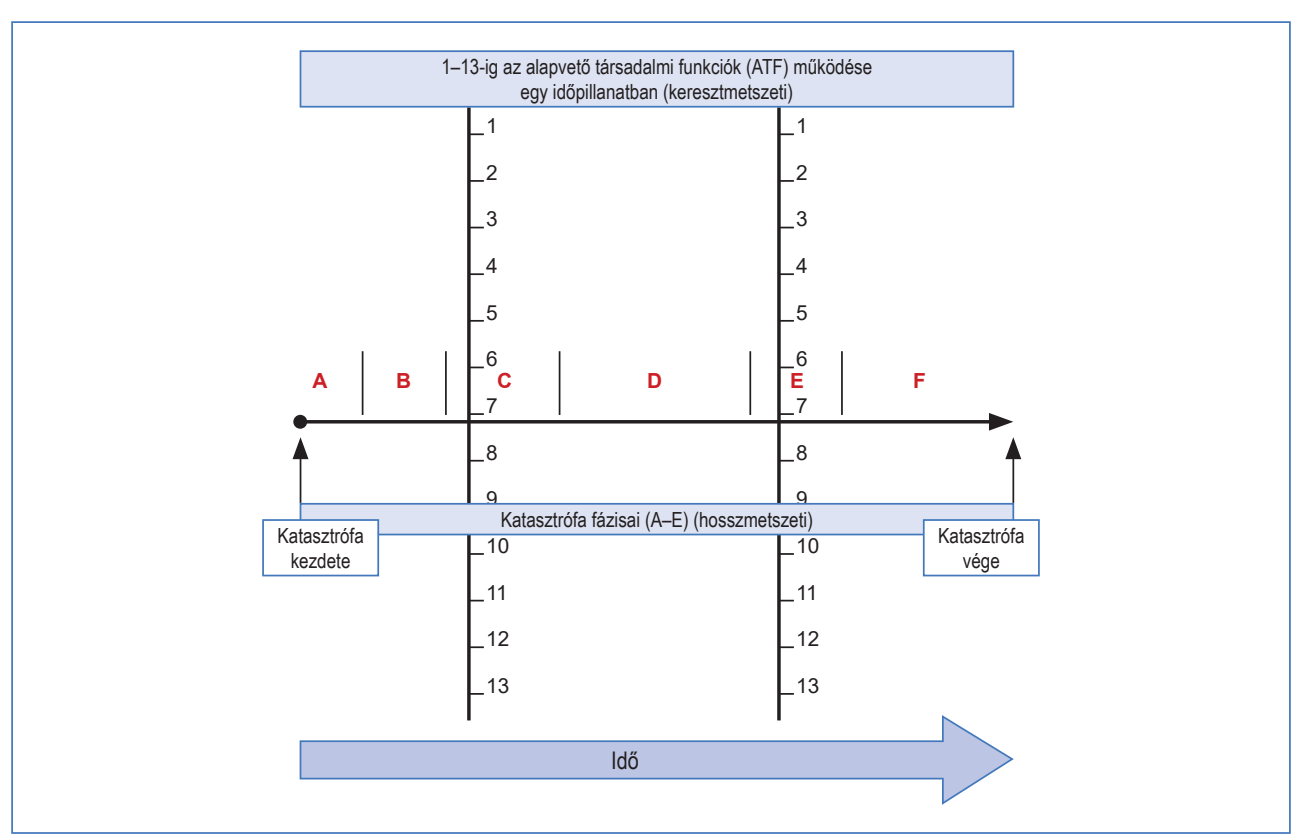

3. ábra. A katasztrófák lefolyásának hossz-és keresztmetszete (Forrás: Scandinavian Journal of Public Health, 2014, 42: 19.) 
tív végrehajtás során mindkét módszer használatos és minkét módszer az adatgyüjtéssel kezdődik.

A megfelelően kiválasztott és konszenzuson alapuló adatsorral az alap társadalmi funkciók (ATF) keresztmetszeti értékelését elvégezve egy pillanatképet kapunk a katasztrófa menetének folyamatáról. Az operatív keret segítséget nyújt nemcsak a vizsgált ATF változók értékeinek rögzítésében, hanem a kapott információ felhasználásával a katasztrófa-segítségnyújtás „testre is szabható”. A megfelelö gondossággal gyüjtött adatok és a helyi rendszert ismerő vezetőkkel, illetve döntéshozókkal történő megbeszélések alapvető segítséggel bírnak a kritikus beavatkozások megtervezéséhez. A folyamat további elemei az értékelő elemzést [1] követően a szükségletek felmérése [2], a stratégia elkészítése [3], a beavatkozás típusának kiválasztása [4], a végrehajtási/operatív terv elkészítése [5], a kiválasztott beavatkozások végrehajtása [6] és végül a hatások elemzése és értékelése [7]. Az operatív keret biztosítja a katasztrófa kutatás evidencia alapú tudományos megközelítését és lehetővé teszi a katasztrófák standardizált vizsgálatát és összehasonlíthatóságát.

\section{Magyarországi bevezethetőség - az Utstein módszer hazai alkalmazása}

Ami a katasztrófák és a katasztrófa medicinával kapcsolatosan a fentiekben már megemlítésre került - a különböző iskolák, szervezetek és országok közötti egységes szemlélet és módszertan hiánya, ideértve a definíciók, a strukturált és objektív adatgyüitést, az alkalmazott indikátorokat, az elemzési és értékelési metodikát, illetve a kutatási és fejlesztési irányokat - véleményünk szerint az nagy- részt a magyarországi viszonyokra nézve is helytálló. Ugyanakkor az is elmondható, hogy bizonyos szervezeti elemek már jelenleg is adottak a katasztrófa-orvostan tudományának művelésére és oktatására, elsősorban az egyes egyetemeken, illetve tudományos társaságokban.

A katasztrófa-orvostannal kapcsolatban egy új, feljövőben lévő tudományágról beszélünk, aminek mindenki érzi a fontosságát, viszont nincsenek még lefektetve annak széleskörü, nemzetközi konszenzussal elfogadott tudományos sarokkövei és módszertana, ezek kidolgozása jelenleg folyik. A szereplők sokszínűsége és számos esetben gyökeresen eltérő érdekei miatt ez a feladat nem tünik egyszerünek és semmiképpen sem gyorsan kivitelezhetönek. Véleményünk szerint az Utstein módszer kiválóan alkalmas arra, hogy - megfelelően adaptálva - megadja a hazai katasztrófa medicina kutatás elméleti kiindulási alapjait és irányát, ami elengedhetetlen feltétele a hazai szakmai konszenzus megteremtésének és az együttműködési lehetőségek kidolgozásának a megkezdésére. A kutatási ambíció nagyságát tekintve úgy véljük, hogy ez a konszenzusos megközelítés elegendő munkát és feladatot tud adni minden magyarországi katasztrófavédelmi és, katasztrófa-egészségügyi kutatással foglalkozó szervezetnek és műhelynek.

Magyarországnak a Sendai Keretegyezményben megfogalmazott célok és prioritások elérésében segítségére lehetnek az Utstein módszertanon alapuló kutatók által feltárt és megerősített módszertanok és eredmények, melyeket közvetlenül felhasználva a kormányzat demonstrálhatja elkötelezettségét az ország katasztrófákkal szembeni ellenálló képességének növelésére.

Az Utstein módszer itthoni bevezetése elképzelésünk szerint több lépcső- 
ben történne. Első lépésként az itthoni kulcsszereplők megismernék a módszer lényegét és kidolgozásra kerülne a pontos menetrend és szerepmegosztás. Ezt követően - vagy inkább ezzel párhuzamosan - a résztvevők kifejlesztenék a módszer oktatásának tematikáját, a honvédegészségügyben széleskörüen alkalmazott instruktor képzés (Train the Trainer) elvét alkalmazva.

Az elsődleges tapasztalatokat felhasználva a későbbiek során a képzés akkreditálásra kerülne mind hazai, mind pedig nemzetközi vonalon és része lehetne a hazai egyetemi graduális és posztgraduális képzésnek.

Fentieken túl, megfelelően adaptálva és akkreditálva, a módszer oktatása beépülhetne a honvéd-, katasztrófa és rendvédelem orvostani szakorvos képzés kurrikulumába, ilyen módon - reményeink szerint - hozzájárulva a terület krónikus szakember hiányának enyhítéséhez.

Hosszabb távon - megfelelő szakembergárda megléte esetén és az Utstein csoport tagjaként szakembereink számára biztosítva lenne a nemzetközi koordinációs és együttműködési lehetőség, a magyar katasztrófa-orvostan rövid időn belül becsatlakozhatna a nemzetközi kutatás és együttműködés fösodrába. A szerzők eddigi nemzetközi tapasztalata alapján még az sem kizárható, hogy megfelelő ambíció és akarat, valamint a szükséges feltételrendszer biztosítása esetén idővel hazánk akár regionális vezető szerep betöltésére is képes lehet.

A szerzők a katasztrófa medicina Utstein módszer szerinti további részletes és átfogó megtárgyalását fenntartják a később megjelenésre szánt publikációik részére. Az UKEM eredményeit kizárólag a Munkacsoportban dolgozó szerzők jogosultak közzétenni.

\section{Irodalom}

[1] Health disaster management: guidelines for evaluation and research in the Utstein Style. Volume I. Conceptual framework of disasters. Task Force on Quality Control of Disaster Management. Prehospital and Disaster Medicine, 2003, 17; suppl 3:1-177.

[2] Health disaster management: guidelines for evaluation and research in the Utstein Style. Volume II. Structure framework, operational framework, and preparedness. Sundnes K.O. (guest editor). Task Force on Quality Control of Disaster Management. Scand. J. Public Health, 2014, 42 (14 suppl): 1-195.

DOI: $10.1177 / 1403494813514914$

[3] Pretto, E., Safar, P.: National Medical Response to Mass Disasters in the United States. Are We Prepared? JAMA 266(9): 1259-1266, 1991.

DOI: 10.1001/jama.1991.03470090093038

[4] Klain, M., Ricci, E., Safar, P. et al: Disaster Reanimatology Potentials: a structured interview study in Armenia I. Methodology and Preliminary results. Prehospital and Disaster Medicine, 1989, 4:135-152.

DOI: $10.1017 /$ S1049023X00029939

[5] Comfort. L., Tekin, A., Pretto, E. et al.: Time, Knowledge, and Action: The Effect of Trauma Upon Community Capacity For Action. Int. Journal of Mass Emergencies and Disasters, 1998, 16(1)

[6] Yeskey, K., Miller, A.: Science Unpreparedness. Disaster Medicine and Public health Preparedness. 2015, 9(4): 444-445. DOI: $10.1017 / \mathrm{dmp} .2015 .53$

[7] Creswell, J. W.: Mixed-method research: Introduction and application. In G. Cizek (Ed.), Handbook of educational policy. San Diego, CA: Academic Press, 1999.

[8] Major L. (szerk): A katasztrófa-felszámolás egészségügyi alapjai, Semmelweis Kiadó, Budapest, 2010.

[9] Kóródi Gy:: Interdiszciplináris problémamegoldás a katasztrófa-reagáló erők egészség-védelmében. Hadtudományi Szemle, 2016, 2: 9. 
[10] Kóródi Gy:: The role of the Institute of Disaster Management of National University of Public Service in the System of the Hungarian Voluntary Rescue Organizations: Searching, Rescue and First Aid, NISPAcee Annual Conference, 2014.

[11] Svéd L., Vekerdi Z.: Algoritmusok a katasztrófa helyzetek egészségügyi biztosításához. Honvédorvos, 2008, 1-2:16-26.

[12] Sendai Framework for Diseaster Risk Reduction 2015-2030 http://www.unisdr.org/ files/43291_sendaiframeworkfordrren.pdf

[13] United Nations Office for Disaster Risk Reduction http://www.unisdr.org

\section{Brig.Gen. I. Kopcsó MDMC, PhD, R. Balázs MD}

\section{Finding consensus on the scientific approach of standardized disaster research based on the Utstein Guidelines}

A goal of disaster medicine is the conduct of studies to enable evidence-based learning that will translate into prevention or reduction of the adverse effects of a disaster on human health and the health system infrastructure.

Due to the complexity of the subject and the different opinions of the nations and NGOs on the management procedures of the disasters, there is no consensus on priorities or best practice methodology for disaster evaluation and for conducting of studies.

To offer a possible consensus on the standardization of disaster research the Utstein Task Force of Disaster Medicine was established; an international panel of public health experts and disaster medicine practitioners. The Task Force - which the authors are members of -, identifies the priorities and proposes solutions concerning the design and conduct of such studies.

The authors aim to introduce the Utstein Guidelines to the Hungarian research of health disaster management and relief planning and to commence the education and training on the subject in order to find the common understanding between the different players.

Keywords: disaster, security, disaster medicine, best practice, Utstein guidelines, Sendai Framework, qualitative and quantitative analysis, indicators

Dr. Kopcsó István o. ddtbk. PhD 1134 Budapest, Róbert Károly krt. 44. 